\title{
Comparison of Monocyte and Alveolar Macrophage Antibody- Dependent Cellular Cytotoxicity and Fc-Receptor Activity ${ }^{1}$
}

\author{
David M. Garagiola, Thomas K. Huard, and Albert F. Lobuglio
}

Simpson Memorial Institute, University of Michigan, Ann Arbor, Michigan 48109

Received June 12, 1981; accepted August 9, 1981

\begin{abstract}
The cytotoxic potential of rabbit peripheral blood monocytes and alveolar macrophages in antibody-dependent cellular cytotoxicity $(\mathrm{ADCC})$ toward both erythrocyte $\left(\mathrm{RBC}_{\mathrm{ox}}\right)$ and tumor cell (CEM T-lymphoblast) targets was examined. ADCC was measured in a 4-hr ${ }^{51} \mathrm{Cr}$ release assay. Alveolar macrophages were more efficient at killing the tumor cell targets (optimally sensitized with rabbit antisera) than monocytes at similar effector cell/target cell $(\mathrm{E} / \mathrm{T})$ ratios. Tumor cell targets sensitized with seven different antisera (anti-CEM) were lysed by alveolar macrophages but not by the monocytes. In marked contrast, the monocytes were more effective at lysing the sensitized erythrocyte target cells. The degree of cytolysis of $R B C_{o x}$ and CEM was dependent on the E/T ratio and the degree of sensitization of these target cells. It was demonstrated that the effector cell selectivity in ADCC was directly related to their ability or inability to bind the sensitized target cells as determined by Fc-receptor rosette formation. The transition from monocyte to macrophage may, therefore, have resulted in an alteration in the criteria necessary for Fc-receptor binding to antibody-sensitized target cells and subsequent ADCC.
\end{abstract}

\section{INTRODUCTION}

Peripheral blood monocytes are the circulating precursors of the tissue-bound macrophages. Both cell populations are directly involved in antigen processing and clearance, and play an active role in the regulation of the immune response. The cells are derived from pluripotent stem cells generated in the bone marrow $(1,2)$. Although monocytes and macrophages may have unique functional characteristics, they share certain membrane receptors including the receptor for $\mathrm{C} 3 \mathrm{~b}(3,4)$ and for the Fc portion of $\operatorname{IgG}(5-8)$. Both ccll populations have been shown to be capable of binding soluble immune complexes and antibody-sensitized erythrocytes $\left(\mathrm{EA}^{2}\right)$ (6-9), and have been shown to effectively lyse EA in antibody-dependent cellular cytotoxicity $(\mathrm{ADCC})((10-13)$; as reviewed in (14-16)). More recently,

\footnotetext{
'This work was supported in part by National Cancer Institute Grant Ca 25641-02 and National Institutes of Health Grant AI 17139-01.

${ }^{2}$ Abbreviations used: ADCC, antibody-dependent cellular cytotoxicity; CEM, human CEM T-cell lymphoblasts; E/T, effector to target ratio; FCS, fetal calf serum; HBSS, Hanks' balanced salt solution; PBS, phosphate-buffered saline; RBC $\mathrm{C}_{\text {ox }}$, ox red blood cells; SBSS, Seligmann's balanced salt solution; SRBC, sheep red blood cells; NZW, New Zealand White rabbits; SPA, Staph.-protein A; EA, antibodysensitized erythrocytes; TA, antibody-sensitized tumor cells.
} 
human monocytes have been shown to be capable of killing sensitized tumor cells in $\operatorname{ADCC}(17,20)$, as well.

In this investigation, we have examined the cytotoxic potential of rabbit peripheral blood monocytes and alveolar macrophages in ADCC toward both erythrocyte and tumor cell targets. The alveolar macrophages were clearly more efficient at killing the sensitized tumor cells, while the monocytes were more effective at lysing erythrocytes. This effector cell selectivity was directly related to Fc-receptor-mediated binding of the target cells and was dependent on the degree of sensitization of the target cells. The differentiation from monocyte to macrophage may, therefore, be accompanied by changes in criteria required for Fc-receptor-mediated binding and lysis of antibody-sensitized targets.

\section{MATERIALS AND METHODS}

\section{Animals}

Normal healthy female 5-kg New Zealand White (NZW) rabbits (Langshaw Distributors, Haslett, Mich.) were used as a source of both monocytes and alveolar macrophages. Rabbits were maintained in the animal care facility of Simpson Memorial Research Institute. Food and water were available ad libitum. No antibiotics or other drugs were administered.

\section{Effector Cells}

Monocytes. Rabbit monocytes were isolated from the peripheral blood of a single rabbit for each experiment. The blood was collected by venipuncture of the central ear artery into $5 \%$ EDTA $(0.3 \mathrm{ml} / 10 \mathrm{ml}$ blood $)$. Mononuclear cells were isolated by Ficoll-Hypaque density gradient centrifugation (19). Briefly, the blood was diluted 1:2 in Seligmann's balanced salt solution (SBSS), then centrifuged at $1150 \mathrm{~g}$ for 25 min through Ficoll-Hypaque. The mononuclear cells were collected, washed twice, and resuspended in SBSS. Monocytes were then isolated from the mononuclear cell suspension as described by Shaw et al. (20). Briefly, $50 \times 10^{6}$ mononuclear cells $(1 \mathrm{ml})$ were added to $100-\mathrm{mm}$ tissue culture plates (Corning No. 25020) containing $10 \mathrm{ml}$ of Hanks' balanced salt solution (HBSS) supplemented with $13 \%$ autologous serum. After incubation for $90 \mathrm{~min}$ at $37^{\circ} \mathrm{C}$ in a humidified atmosphere of $5 \% \mathrm{CO}_{2}$ in air, the adherent cell monolayer was washed vigorously five times with complete medium consisting of RPMI 1640, 10\% heat-inactivated fetal calf serum (FCS), $100 \mathrm{U} / \mathrm{ml}$ penicillin, and $100 \mu \mathrm{g} / \mathrm{ml}$ streptomycin. After washing, the adherent cells were incubated for $2 \mathrm{~min}$ in $5 \mathrm{ml}$ of cold $0.2 \%$ EDTA in physiological saline containing $0.1 \%$ bovine serum albumin. The adherent cells were harvested by gentle scraping with a rubber policeman, washed twice in complete medium, and adjusted to the appropriate concentrations (as indicated in the text). Cell viability was determined by trypan blue dye exclusion. The adherent cell suspension was characterized by morphology (Wright stain), phagocytosis of opsinized zymosan (21) and staining for the nonspecific esterase (22) and found to be $\geq 95 \%$ monocytes by these three criteria. Cell viability was $\geq 95 \%$.

Macrophages. Rabbit alveolar macrophages were obtained by pulmonary lavage (23). Briefly, rabbits were sacrificed and the lungs dissected free. The lungs were filled with $50 \mathrm{ml}$ of HBSS and massaged gently and the cell suspensions aspirated. 
This procedure was repeated an additional three times. The cell suspensions were combined, washed twice in complete medium, and adjusted to the appropriate concentrations (as indicated in the text). Viability and purity were assessed as for the monocytes. The alveolar macrophages were $\geq 95 \%$ viable and $\geq 95 \%$ pure by all three criteria.

\section{Target Cells}

Erythrocytes. Fresh ox erythrocytes $\left(\mathrm{RBC}_{\mathrm{ox}}\right)$ (Colorado Serum Company Laboratories, Denver, Colo.) were washed three times in HBSS and radiolabeled by incubating $250 \times 10^{6}$ cells with $30 \mu \mathrm{Ci}$ of $\mathrm{Na}_{2}{ }^{51} \mathrm{CrO}_{4}$ (New England Nuclear, Boston, Mass.) for $60 \mathrm{~min}$ at $37^{\circ} \mathrm{C}$. The $\mathrm{RBC}_{\mathrm{ox}}$ were then washed two times with HBSS and sensitized by incubating $50 \times 10^{6}$ targets with $50 \mu \mathrm{l}$ of varying dilutions of rabbit anti-sheep red blood cell (SRBC) antisera (Cordis Corp., Miami, FL) for $45 \mathrm{~min}$ and $37^{\circ} \mathrm{C}$ with gentle agitation every $15 \mathrm{~min}$. The cell concentration was adjusted to $2 \times 10^{6} / \mathrm{ml}$ for use in all ADCC experiments. Radiolabeled $\mathrm{RBC}_{\text {ox }}$ incubated with phosphate-buffered saline (PBS) were used as control (nonsensitized) target cells.

Tumor cells. A human T-cell lymphoblast cell line (CEM, ref. (24)) was radiolabeled by incubation of $10 \times 10^{6}$ cells in $0.3 \mathrm{ml}$ of a Tris-phosphate buffer (25) containing $100 \mu \mathrm{Ci}$ of $\mathrm{Na}_{2}{ }^{51} \mathrm{CrO}_{4}$ for $90 \mathrm{~min}$ at $37^{\circ} \mathrm{C}$ with gentle agitation every $15 \mathrm{~min}$. The CEM were subsequently washed twice in complete medium and sensitized by incubation of $2.5 \times 10^{6} \mathrm{CEM}$ with $50 \mu \mathrm{l}$ of varying dilutions of rabbit anti-CEM antisera for $45 \mathrm{~min}$ at $37^{\circ} \mathrm{C}$ with gentle agitation every $15 \mathrm{~min}$. The cells were washed two times in complete medium and adjusted to $2 \times 10^{5} / \mathrm{ml}$ for use in all ADCC experiments. Radiolabeled CEM incubated with PBS were used as control (nonsensitized) target cells.

\section{Antisera}

Rabbit anti-SRBC antiserum (7 S IgG; Cordis Corporation, Miami, Fla.) was used at dilutions of 1:2, 1:8, 1:32, and 1:128 (in PBS) to sensitize the $\mathrm{RBC}_{\text {ox }}$ targets. $\mathrm{RBC}_{\mathrm{Ox}}$ (instead of $\mathrm{SRBC}$ ) were used as target cells and sensitized with anti-SRBC antisera to avoid the hemagglutination that occurred from the sensitization of SRBC with homologous antisera [even at dilutions (1:128) which would not mediate ADCC].

Anti-CEM T-lymphoblast antisera was raised in rabbits as previously described (20). The antisera was used undiluted, or at dilutions of 1:8, 1:32 and 1:128 in PBS to sensitize CEM target cells. All antisera were heat inactivated at $56^{\circ} \mathrm{C}$ for $30 \mathrm{~min}$ prior to use for sensitizing the target cells.

\section{Antibody-Dependent Cellular Cytotoxicity (ADCC)}

The ability of rabbit monocytes and alveolar macrophages to lyse antibody-sensitized target cells was determined by a $4-\mathrm{hr}{ }^{51} \mathrm{Cr}$-release assay (20). Briefly, 0.1 $\mathrm{ml}$ of the effector cells (at various concentrations as indicated in the text) was mixed with $0.1 \mathrm{ml}$ of the antibody-sensitized $\mathrm{RBC}_{\mathrm{ox}}\left(2 \times 10^{6} / \mathrm{ml}\right)$ or CEM (2 $\times 10^{5} / \mathrm{ml}$ ) target cells in $0.3-\mathrm{ml}$ flat-bottom well tissue culture plates (Costar, Cambridge, Mass.). The plates were centrifuged for $3 \mathrm{~min}$ at $50 \mathrm{~g}$ to initiate cell- 
cell contact. Plates were incubated at $37^{\circ} \mathrm{C}$ for $4 \mathrm{hr}$ in a humidified atmosphere of $5 \% \mathrm{CO}_{2}$ in air. After $4 \mathrm{hr}, 100 \mu \mathrm{l}$ of supernatant was aspirated from each well to determine the amount of ${ }^{51} \mathrm{Cr}$ released. Percentage cytotoxicity was calculated by the formula

$$
\% \mathrm{ADCC}=(A-B) /(C-B) \times 100,
$$

where $(A)=$ mean counts per minute in supernatants from wells (triplicate) containing both effector and target cells; $(B)=$ mean counts per minute in supernatants from wells containing target cells alone (spontaneous release); and $(C)=$ mean counts per minute of the total number of target cells added to each well. Spontaneous release from $\mathrm{RBC}_{\mathrm{ox}}$ was $\leq 6 \%$ and from $\mathrm{CEM}$ targets ranged from 6 to $15 \%$.

\section{Determination of Target Cell Binding}

Effector cell binding of $\mathrm{RBC}_{\mathrm{Ox}}$ was determined by modification of the EA (antibody-sensitized erythrocyte) rosette formation assay (26) as previously described (27). To determine the binding of $\mathrm{RBC}_{\mathrm{ox}}, 100 \mu \mathrm{l}$ of purified effector cells (10 $\times 10^{6} / \mathrm{ml}$ ) was mixed with an equal volume of the antibody-sensitized target cells $\left(250 \times 10^{6} / \mathrm{ml}\right)$ and sedimented by centrifugation at $100 \mathrm{~g}$ for $3 \mathrm{~min}$. The cell pellet was incubated at an ambient temperature for $15 \mathrm{~min}$ and the cells were resuspended in their own supernatant. One drop of cell suspension was mixed with one drop of $0.1 \%$ toluidine blue and examined microscopically. Effector cells binding 0, 1-4, or $\geq 5$ sensitized $\mathrm{RBC}_{\text {ox }}$ were enumerated. Duplicate slides were examined and 200 cells were counted on each slide.

To determine the effector cell binding of sensitized CEM tumor cell targets, 100 $\mu l$ of purified monocytes or alveolar macrophages $\left(1.0 \times 10^{5} / \mathrm{ml}\right)$ was mixed with an equal volume of the antibody-sensitized target cells $\left(2.5 \times 10^{6} / \mathrm{ml}\right)$ and sedimented as described above. After incubation for $15 \mathrm{~min}$ the cells were resuspended and the cell suspension was stained for the nonspecific esterase to differentiate the effector cells from the CEM T-lymphoblast targets. The cell suspension was examined microscopically and effector cells binding $0,1.4$, or $\geq 5$ sensitized CEM tumor cells were enumerated.

\section{Quantitation of Target Cell-Bound IgG}

The amount of antibody ( $\operatorname{IgG}$ ) on the target cell surface was quantitated using ${ }^{125}$ I-radiolabeled protein A (SPA) from Staphylococcus aureus (Cowan I) as previously described (28).

\section{RESULTS}

\section{Monocyte and Macrophage ADCC of Erythrocyte Targets}

We compared monocyte and macrophage ADCC to $\mathrm{RBC}_{\text {ox }}$ targets using (a) varying numbers of effector cells, and (b) target cells sensitized with varying dilutions of antisera. As seen in Fig. 1, monocyte ADCC to $R B C_{0 x}$ was significantly higher than macrophage ADCC across a wide range of effector cell concentrations $(P<0.05$ by $t$ test $)$. Increasing the number of monocytes produced increasing 


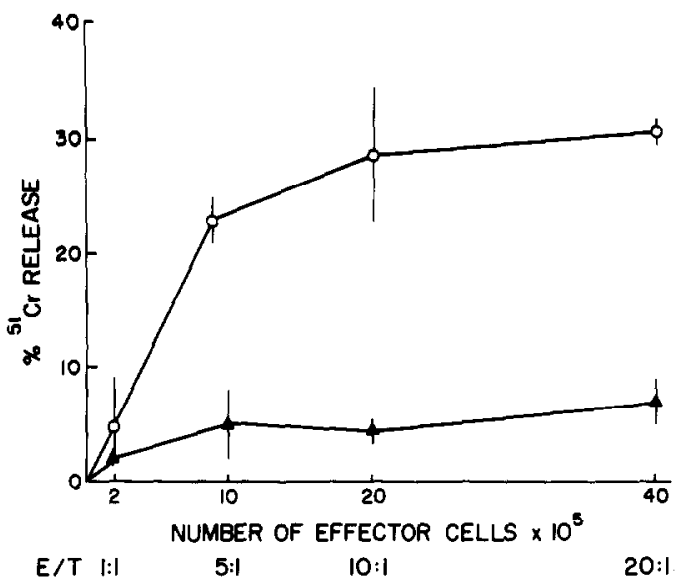

FIG. 1. The effect of varying numbers of monocytes $(O)$ and alveolar macrophages $(\Delta)$, on ADCC to $\mathrm{RBC}_{\text {ox }}$ targets. Effector cells were incubated with $2 \times 10^{5} \mathrm{RBC}_{\mathrm{Ox}}$ sensitized with rabbit anti-SRBC antisera diluted 1:2 in PBS. The data are presented as the mean percentage ${ }^{51} \mathrm{Cr}$ release \pm SD of triplicate values from at least three experiments. Total cpm $/ 2 \times 10^{5}$ targets was $1800 \pm 200$; spontaneous release was $\leq 6 \%$.

$\mathrm{ADCC}$ up to an effector cell number that was equivalent to an effector/target cell ratio $(E / T)$ of 10:1. Increasing the number of macrophages, however, failed to elevate the small amount of ADCC against the same target cells.

To examine the effect of varying the amount of antibody on the target cell surface, $R B C_{o x}$ were sensitized with varying dilutions of the rabbit anti-SRBC antisera (1:2 to 1:128) (Fig. 2). These antisera dilutions produced a range of molecules of IgG/target cell of 60,000 to 15,000 as determined by the ${ }^{125}$ I-SPA assay. Monocyte ADCC exceeded that of the macrophages at all levels of antibody sensitization of the target cells examined. The degree of monocyte $A D C C$ to $\mathrm{RBC}_{\mathrm{Ox}}$

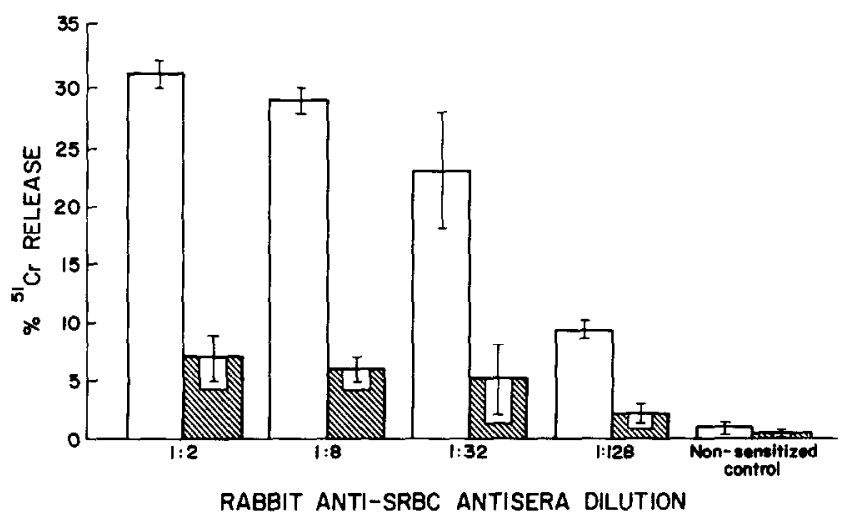

FIG. 2. The effect of varying the degree of target cell sensitization on monocyte $(\square)$ and alveolar macrophage (ADCC to $\mathrm{RBC}_{\mathrm{ox}}$ targets. Effector cells were incubated with $2 \times 10^{5}$ target cells at a $20: 1 \mathrm{E} / \mathrm{T}$ ratio. The data are presented as the mean percentage ${ }^{51} \mathrm{Cr}$ release $\pm \mathrm{SD}$ of triplicate values from at least three experiments. Total $\mathrm{cpm} / 2 \times 10^{5}$ targets was $1800 \pm 200$; spontaneous release was $\leq 6 \%$. 
was dependent upon the degree of antibody sensitization. Neither effector cell produced significant lysis of the nonsensitized target cells at any $E / T$ ratio examined.

\section{Monocyte and Macrophage ADCC of Tumor Cell Targets}

In the same experiments, monocytes and macrophages were examined for their ability to carry out ADCC to antibody-sensitized tumor cells. As seen in Fig. 3, increasing numbers of macrophages produced progressively increasing degrees of ADCC while monocytes failed to produce significant ADCC at any of these effector cell numbers. This is in marked contrast to the target cell preferences exhibited for $\mathrm{RBC}_{\mathrm{Ox}}$, where monocytes were more effective at ADCC. As shown in Fig. 4, using dilutions of sensitizing antisera to yield varying levels of $\mathrm{IgG} /$ target cell from 400,000 to 25,000 (by ${ }^{125}$ I-SPA assay) revealed that the degree of ADCC by macrophages was dependent on the amount of antibody on the target cell surface. Monocytes failed to carry out ADCC at any antibody concentration tested. Nonsensitized tumor cells were not lysed by either effector cell population.

We also examined six other rabbit antisera to these target cells for their ability to mediate ADCC by monocytes and macrophages. As seen in Table 1, monocytes produced little or no ADCC with these antibody-sensitized tumor cells while the macrophages produced varying degrees of ADCC depending on the antisera used.

\section{Monocyte and Macrophage Ability to Bind Antibody-Sensitized Target Cells}

In order to determine whether the differences in effector cell ADCC might be related to initial Fc-receptor binding or to a postbinding event, we examined the ability of monocytes and macrophages to bind these antibody-sensitized target cells. Figure 5 illustrates typical rosettes formed between effector cells and antibodysensitized $\mathrm{RBC}_{\mathrm{ox}}(5 \mathrm{a})$ or tumor cells $(5 \mathrm{~b})$. As seen in Table 2, monocytes were

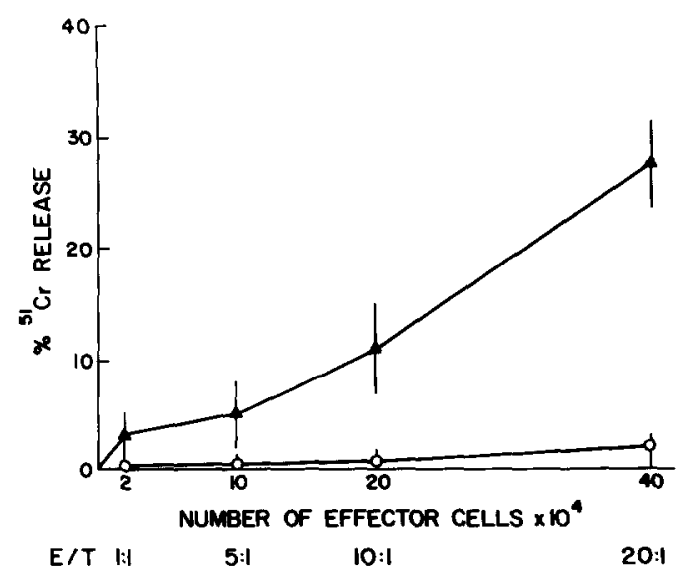

FIG. 3. The effect of varying numbers of monocytes $(O)$ and alveolar macrophages (A), on ADCC to CEM T-lymphoblast targets. Effector cells were incubated with $2 \times 10^{4} \mathrm{CEM}$ sensitized with undiluted anti-CEM antisera. The data are presented as the mean percentage ${ }^{51} \mathrm{Cr}$ release $\pm \mathrm{SD}$ of triplicate values from at least three experiments. Total $\mathrm{cpm} / 2 \times 10^{4}$ targets was $12,000 \pm 2000$; spontaneous release ranged from 6 to $15 \%$. 


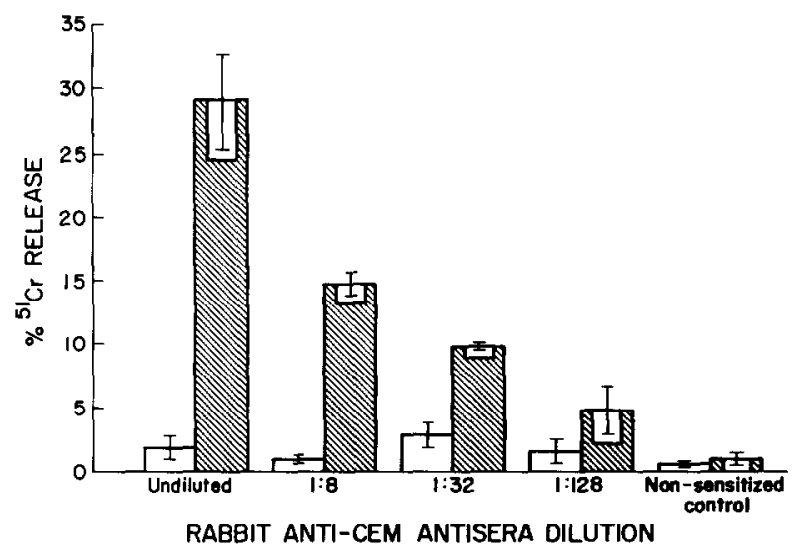

FIG. 4. The effect of varying the degree of target cell sensitization on monocyte $(\square)$ and alveolar macrophage ( ADCC to CEM T-lymphoblast targets. Effector cells were incubated with $2 \times 10^{4}$ target cells at a 20:1 E/T ratio. Data are presented as a mean percentage ${ }^{51} \mathrm{Cr}$ release $\pm \mathrm{SD}$ of triplicate values from at least three experiments. Total $\mathrm{cpm} / 2 \times 10^{4}$ targets was $12,000 \pm 2000$; spontaneous release ranged from 6 to $15 \%$.

able to bind antibody-sensitized $\mathrm{RBC}_{\mathrm{ox}}$ while over $80 \%$ of these cells failed to bind the antibody-sensitized tumor cells. Conversely, few macrophages were able to bind antibody-sensitized $\mathrm{RBC}_{\mathrm{ox}}$ but a majority were able to bind antibody-sensitized tumor cells. Thus, the differences seen in terms of lysis of target cells correlated well with the ability of the effector cells to recognize and bind the antibody-sensitized targets. In the absence of antibody, little or no target cell binding was seen with either effector cell population.

\section{DISCUSSION}

The membrane Fc-receptors of monocytes and macrophages have been shown to be capable of binding soluble immune complexes, aggregated IgG, and antibody-

TABLE 1

Monocyte and Alveolar Macrophage ADCC to CEM Tumor Cells

\begin{tabular}{lrrrrrrr}
\hline & \multicolumn{7}{c}{ Percentage ADCC } \\
\cline { 2 - 7 } Cell source & $\mathbf{E} / \mathrm{T}^{b}$ & $\mathrm{I}^{c}$ & 2 & 3 & 4 & 5 & 6 \\
\hline \multirow{2}{*}{ Alveolar } & $20: 1$ & 9 & 52 & 35 & 27 & 22 & 16 \\
Imacrophage & $10: 1$ & 9 & 54 & 24 & 17 & 12 & 9 \\
& $5: 1$ & 4 & 37 & 12 & 9 & 6 & 4 \\
Monocyte & $1: 1$ & 0 & 10 & 2 & 2 & 1 & 1 \\
& $20: 1$ & 0 & 7 & 1 & 5 & 6 & 1 \\
& $10: 1$ & 0 & 3 & 0 & 3 & 3 & 1 \\
& $5: 1$ & 0 & 1 & 0 & 1 & 1 & 1 \\
& $1: 1$ & 0 & 0 & 0 & 0 & 0 & 0 \\
\hline
\end{tabular}

${ }^{a}$ Percentage $\mathrm{ADCC}=$ mean percentage $\mathrm{ADCC}$ from triplicate samples.

${ }^{b} \mathrm{E} / \mathrm{T}$, effector cell:target cell ratio.

c $1-6$ refer to six different rabbit anti-CEM T-Lymphoblast antisera preparations. 


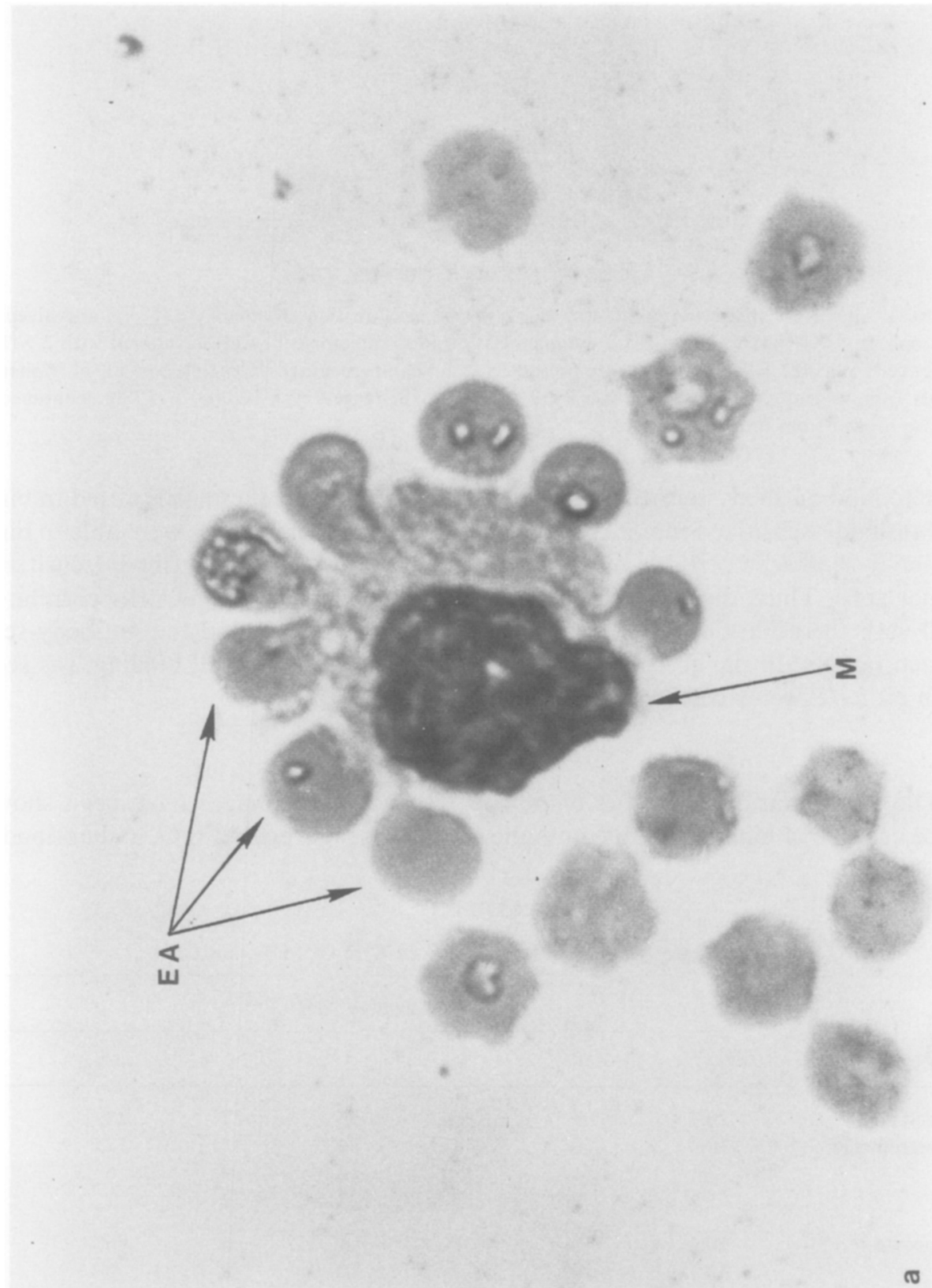




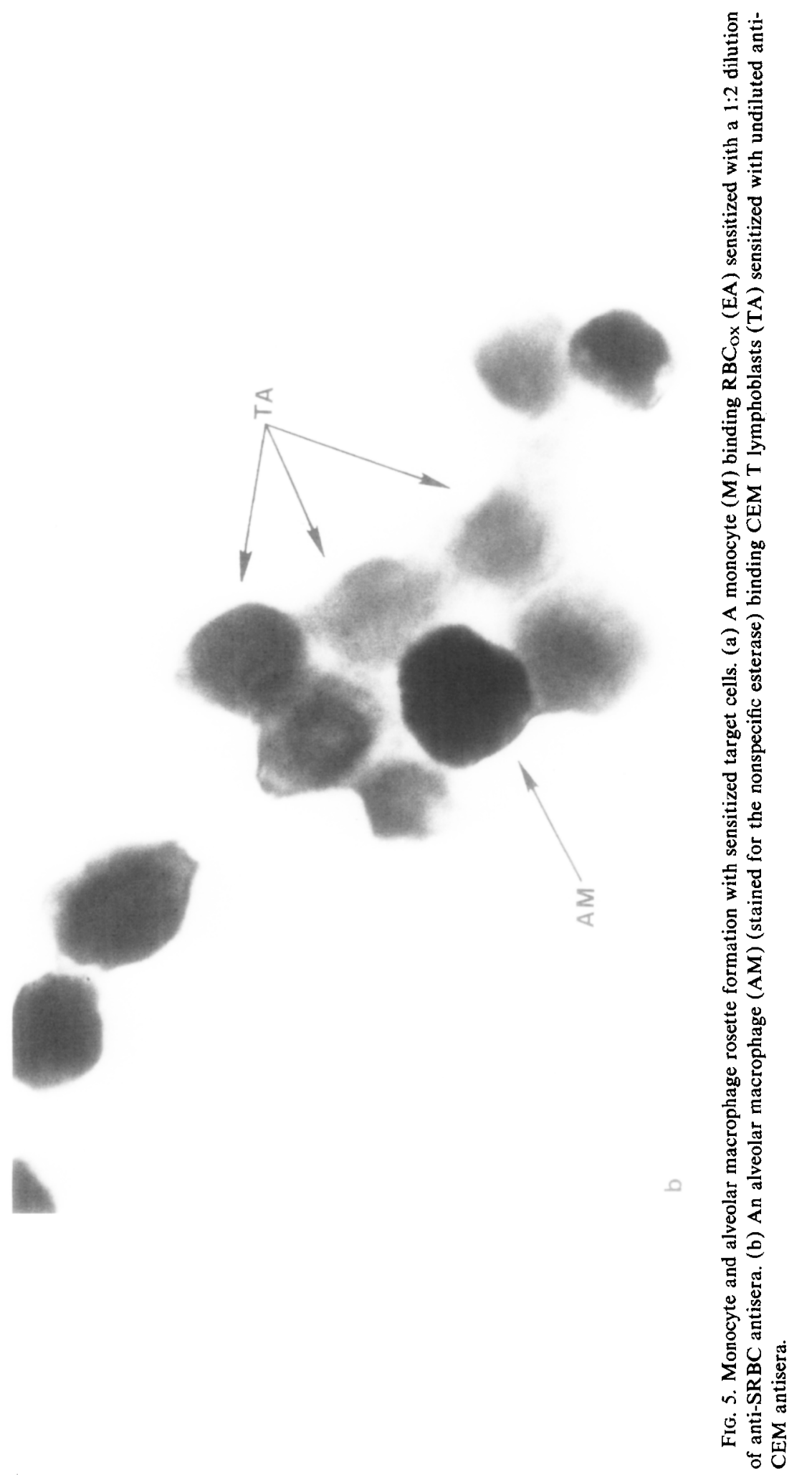


TABLE 2

Target Cell Binding by Rabbit Monocytes and Alveolar Macrophages

\begin{tabular}{|c|c|c|c|}
\hline \multirow{2}{*}{$\begin{array}{l}\text { Target } \\
\text { cell }^{a}\end{array}$} & \multicolumn{3}{|c|}{$\begin{array}{l}\text { Percentage monocytes binding varying numbers } \\
\text { of target cells } s^{b}\end{array}$} \\
\hline & 0 & $1-4$ & $\geqslant 5$ \\
\hline EA & $15 \pm 3$ & $45 \pm 5$ & $40 \pm 9$ \\
\hline $\mathrm{E}$ & $96 \pm 3$ & $4 \pm 2$ & $0 \pm 0$ \\
\hline TA & $83 \pm 4$ & $16 \pm 4$ & $1 \pm 1$ \\
\hline \multirow[t]{3}{*}{$\mathrm{T}$} & $98 \pm 2$ & $2 \pm 2$ & $0 \pm 0$ \\
\hline & \multicolumn{3}{|c|}{$\begin{array}{c}\text { Percentage of alveolar macrophages binding varying } \\
\text { numbers of target cells }\end{array}$} \\
\hline & 0 & $1-4$ & $\geqslant 5$ \\
\hline EA & $74 \pm 5$ & $22 \pm 3$ & $4 \pm 3$ \\
\hline E & $97 \pm 3$ & $3 \pm 3$ & $0 \pm 0$ \\
\hline TA & $6 \pm 2$ & $23 \pm 3$ & $71 \pm 5$ \\
\hline $\mathrm{T}$ & $92 \pm 4$ & $7 \pm 3$ & $1 \pm 1$ \\
\hline
\end{tabular}

${ }^{a} \mathrm{E}$ indicates control $\mathrm{RBC}_{\mathrm{ox}}$; EA indicates $\mathrm{RBC}_{\mathrm{Ox}}$ sensitized with a 1:2 dilution of rabbit anti-SRBC antisera; $T$ indicates control CEM tumor cells; TA indicates CEM tumor cells sensitized with undiluted rabbit anti-CEM antisera.

${ }^{b}$ Percentage expressed as the mean $\pm 1 \mathrm{SD}$ of $\geqslant$ three experiments.

coated target cells (6-9). By this Fc-receptor:antibody interaction, these effector cells are also capable of postbinding cytolysis of sensitized target cells in ADCC (10-16). The expression of Fc-receptor activity may vary with different cell populations. For example, Rhodes (29) has presented evidence that guinea pig peritoneal macrophage subpopulations may vary in avidity of their Fc-receptor for immune complexes. Hunninghake and Fauci (18) attempted to compare the ADCC capacity of guinea pig alveolar, spleen, and blood mononuclear phagocytes toward sensitized chicken red blood cells and Chang liver cells. They noted that alveolar macrophages had a cytotoxic capacity against antibody-coated chicken red blood cells greater than that of blood monocytes or splenic macrophages. They were unable to demonstrate significant ADCC to tumor cells by any of these monocytemacrophage cell populations. No studies were done to examine Fc-receptor binding of the target cell preparations.

In this study, we were interested in comparing the ability of rabbit blood monocytes and alveolar macrophages from the same animal with regard to their ability to bind and lyse two different target cells coated with rabbit antibody. In this way, we hoped to gain some insight into potential changes in Fc-receptor-mediated cell functions during the transition from monocytes to tissues macrophages. The results were surprising in that $\mathrm{RBC}_{\mathrm{ox}}$ coated with adequate rabbit $\mathrm{IgG}$ to mediate strong monocyte binding and subsequent target cell lysis were not readily recognized or lysed by alveolar macrophages. Conversely, CEM tumor cells heavily sensitized by rabbit IgG were bound and lysed by alveolar macrophages while serving as poor target cells for binding and lysis by blood monocytes. Clearly, the criteria used by these two cell populations for membrane Fc-receptor interaction with antibody 
displayed on a target cell surface had undergone significant modification in the maturation process from monocyte to tissue macrophage. Recent studies in our laboratory suggest, however, that monocyte Fc-receptor interaction with antibodycoated tumor cells can occur following in vivo activation of monocytes with mycobacteria and their active adjuvant component muramyl dipeptide (38-40).

There have been other examples of effector cells which differ in their criteria for membrane Fc-receptor interaction with antibody displayed on target cell surfaces. Human Fc-receptor-positive lymphocytes ( $K$ cells) and monocytes appear to have membrane $\mathrm{Fc}$-receptors with similar specificities for the $\operatorname{IgG}_{1}$ and $\mathrm{IgG}_{3}$ subclasses of immunoglobulin (30-33). However, these lymphocytes are unable to bind and lyse human red cells coated with certain human antisera (anti-D) while monocytes from the same donor bind and lyse these target cells well (34). Alteration of the distribution of antibody on these red cells (clustering) allows lymphocytes to bind and lyse red cell targets when sensitized with the same anti-D antisera $(28,34)$. These studies suggest that antibody distribution represents a criteria for lymphocyte Fc-receptor interaction with at least some types of antibody-sensitized target cells not shared by the monocyte. In addition, binding of soluble IgG oligomers appears to be similar by human granulocytes, lymphocytes, and monocytes (35). Despite this, ADCC of CEM tumor cells by Fc-receptor-positive human granulocytes has been found to require 100 times the concentration of rabbit antibody on the tumor cell surface than required for either lymphocyte or monocyte ADCC (36). Differences in ability to recognize and lyse antibody-coated target cells by the same cell populations from different species have been reported (37). We have also reported that human monocytes are quite effective at recognition and lysis of the same rabbit antibody-coated CEM target cells (20) that failed to elicit ADCC by rabbit monocytes in this study. Thus, it would appear that different effector cell populations or similar populations of effector cells from different species differ in their criteria for interaction with IgG displayed on target cell surfaces.

The current study extends these observations by indicating that criteria for Fcreceptor interaction with antibody-sensitized target cells can differ dramatically at different stages of differentiation in the monocyte/macrophage cell lineage. These differences may be related to alteration in Fc-receptor requirements for antibody density, distribution, subclass, or other as yet undetermined factors which alter the Fc-receptor interaction with the Fc portion of IgG displayed on cell surfaces. Further, this study indicates that the variation seen in the sensitivity of certain target cells to ADCC by unique effector cell populations can be explained at least in part by variation in Fc-receptor binding of target cells rather than postbinding events.

\section{ACKNOWLEDGMENTS}

The authors wish to thank Ms. Maxine Solvay and Ms. Pam Graham for their technical assistance, and Ms. Helen Ilc and Ms. Jerrie CeBulkey for their assistance in the preparation of this manuscript for publication.

\section{REFERENCES}

1. van Furth, R., and Cohn, Z. A., J. Exp. Med. 128, 415, 1968.

2. van Furth, R., Raeburn, J. A., and van Zwet, T. C., Blood 54, 485, 1979. 
3. Huber, H., Polley, M. J., Lensott, W. D., Fudenberg, H. H., and Muller-Eberhard, H. J., Science $162,1281,1968$.

4. Lay, W. H., and Nussenzweig, V., J. Exp. Med. 128, 991, 1968.

5. Howard, J. G., and Benacerraf, B., Brit. J. Exp. Pathol. 47, 193, 1966.

6. LoBuglio, A. F., Cotran, R. S., and Jandl, J. H., Science 158, 1582, 1967.

7. Arend, W. P., and Mannik, M., J. Exp. Med. 136, 514, 1972.

8. Arend, W. P., and Mannik, M., J. Immunol. 110, 1455, 1973.

9. Daughaday, C. C., and Douglas, S. D., J. Reticuloendothel. Soc. 19, 37, 1976.

10. Holm, G., Int. Arch. Allergy 43, 671, 1972.

11. Walker, W. S., and Demus, A., J. Immunol. 114, 765, 1975.

12. Shaw, G. M., Levy, P. C., and LoBuglio, A. F., Blood 50, 177, 1977.

13. Shaw, G. M., Levy, P. C., and LoBuglio, A. F., Cell. Immunol. 41, 122, 1978.

14. MacLennan, I. C. M., In "Clinical Tumor Immunology" (J. Wybran and M. J. Staquet, Eds.), p. 47. Pergamon, Oxford, 1976.

15. Perlman, P., In "Clinical Immunobiology" (F. H. Bach and R. A. Good, Eds.), Vol. 3, p. 107. Academic Press, New York, 1976.

16. Henney, C. S., In "Mechanisms of Tumor Immunity (S. Cohen and R. T. McCluskey, Eds.), p. 55. Wiley, New York, 1977.

17. Shaw, G. M., Levy, P. C., and LoBuglio, A. F., J. Immunol. 121, 573, 1978.

18. Hunninghake, G. W., and Fauci, A. S., Cell. Immunol. 26, 98, 1976.

19. Bøyum, A., Scand. J. Immunol. 5, 9, 1976.

20. Shaw, G. M., Levy, P. C., and LoBuglio, A. F., J. Clin. Invest. 62, 1172, 1978.

21. Webb, L. S., Keble, B. B., Jr., and Johnson, R. B., Jr., Infect. Immunity 9, 1051, 1974.

22. Tucker, S. B., Pierre, R. V., and Jordan, R. E., J. Immunol. Methods 14, 267, 1977.

23. Myrvik, Q. N., Leake, E. S., and Fariss, B., J. Immunol. 86, 128, 1961.

24. Foley, G. E., Lazarus, H., Farber, S., et al., Cancer 18, 522, 1965.

25. Brunner, K. T., Engers, H. D., and Cerottini, J. C., In "In Vitro Methods in Cell-Mediated and Tumor Immunity" (B. R. Bloom and J. R: David, Eds.), p. 423. Academic Press, New York, 1976.

26. Frøland, S. S., and Wisløff, F., In "In Vitro Methods in Cell-Mediated and Tumor Immunity" (B. R. Bloom and J. R. David, Eds.), p. 137. Academic Press, New York, 1976.

27. Shaw, G. M., Levy, P. C., and LoBuglio, A. F., Clin. Exp. Immunol. 36, 496, 1979.

28. Shaw, G. M., Aminoff, D., Balcerzak, S. P., and LoBuglio, A. F., J. Immunol. 125, 501, 1980.

29. Rhodes, J., J. Immunol. 114, 976, 1975.

30. Wisløf, F., Michaelsen, T. E., and Frøland, S. S., Scand. J. Immunol. 3, 29, 1974.

31. Holm, G., Engwall, E., Hammarström, S., and Natvig, J. B., Scand. J. Immunol. 3, 173, 1974.

32. Urbaniak, S. J., Brit. J. Hematol. 42, 315, 1979.

33. Walker, W. S., J. Immunol. 119, 367, 1977.

34. Shaw, G. M., Levy, P. C., and LoBuglio, A. F., Blood 52, 696, 1978.

35. Alexander, E. L., Titus, J. A., and Segal, D. M., J. Immunol. 123, 295, 1979.

36. Levy, P. C., Shaw, G. M., and LoBuglio, A. F., J. Immunol. 123, 594, 1979.

37. Zighelboim, J., and Gale, R. P., J. Immunol. 113, 1145, 1974.

38. Garagiola, D. M., Huard, T. K., and LoBuglio, A. F., Fed. Proc. 39, 933, 1980.

39. Garagiola, D. M., LoBuglio, A. F., and Huard, T. K., Clin. Res. 28, 733A, 1980.

40. Huard, T. K., Garagiola, D. M., and LoBuglio, A. F., Clin. Res. 29, 369A, 1981. 